\title{
Analisa unjuk kerja alat pembagi tekan pada pompa hydram
}

\section{Analysis of the performance of the pressure divider on the hydram pump}

\section{K. Wardani*}

Balai Wilayah Sungai Nusa Tenggara I - PUPR

Jl. Ahmad Yani No 1 Gerimax Indah Narmada Lombok Barat NTB 83239, Telepon. (0370) 646655.

*Email: kusuma_wardani80@yahoo.com

\section{ARTICLE INFO}

Article History:

Received 10 February 2019

Accepted 04 March 2019

Available online 1 July 2019

Keywords:

Hydram pump

Pressure divisor

Water hammer

Head maximum

\begin{abstract}
Water is source of life for human being, plant and animal. One of effort to complete of water required is by using hydram pump. Hydram pump (Hydraulic ram pump) is a pump that work without required energy from outside for its activated, but work done by exploiting force from source of water. This research purposes to know influence of pressure divisor to water hammer effect and to know influence of pressure divisor to efficiency of hydram pump. This research used hydram pump by the specification of air tube it's $60 \mathrm{~cm}$ height and 3 inches diameter. Elevation of plunge from pump body is $2 \mathrm{~m}$ and elevation of output is $4 \mathrm{~m}$. Height of air tube at pressure divisor that is $20 \mathrm{~cm}, 30 \mathrm{~cm}, 40 \mathrm{~cm}$ and $50 \mathrm{~cm}$ and elevation of variety pressure divisor from body pump is 2 $\mathrm{m}, 2.5 \mathrm{~m}$ and $3 \mathrm{~m}$. The method used in this research is experiment method. The quantitative data made in table and displayed graphically. The results show that the highest of maximum head at $2 \mathrm{~m}$ elevation of pressure divisor from pump body and $20 \mathrm{~cm}$ high of tube, while lowest of maximum head at $3 \mathrm{~m}$ elevation of pressure divisor from pump body and $50 \mathrm{~cm}$ high of tube. The best efficiency at $2 \mathrm{~m}$ elevation of pressure divisor from pump body and $20 \mathrm{~cm}$ high of tube that is $31.62 \%$, while the lowest efficiency at hydram pump installation without of pressure divisor that is only $26.62 \%$.
\end{abstract}

Dinamika Teknik Mesin, Vol. 9, No. 2, Juli 2019, p. ISSN: 2088-088X, e. ISSN: 2502-1729

\section{PENDAHULUAN}

Manusia, hewan dan tumbuh-tumbuhan adalah makluk hidup yang membutuhkan air sebagai sumber kehidupan. Pemenuhan kebutuhan air di daerah-daerah yang berdekatan dengan sumber mata air dengan elevasi yang berada lebih rendah dari sumber air akan lebih mudah, karena dapat dialirkan menggunakan cara gravitasi.

Namun faktanya, terdapat daerah-daerah yang letaknya lebih tinggi dari sumber air. Salah satu contohnya adalah Desa Menemeng. Desa ini terletak di Kecamatan Pringgarata Kabupaten Lombok Tengah Nusa Tenggara Barat. Posisi Desa ini terletak di dataran tinggi, dimana pada pinggiran desa terdapat sungai besar dan terdapat mata air di pinggir tebing kira-kira $2 \mathrm{~km}$ dari pemukiman 
penduduk. posisi pemukiman penduduk terletak di dataran tinggi sekitar $50 \mathrm{~m}$ di atas sumber mata air. Pengambilan air pun masih dilakukan secara manual yaitu dengan cara mengangkut air dari sumber air menggunakan ember (Muliadi dkk, 2015). Hal ini tentu menyulitkan masyarakat yang tinggal di daerah tersebut.

Salah satu upaya untuk mengatasi kesulitan air, terutama di daerah yang elevasinya lebih tinggi dari sumber air seperti daerah tersebut adalah dengan menggunakan pompa. Secara umum, pompa air membutuhkan motor listrik untuk menggerakannya. Motor listrik itu sendiri membutuhkan energi listrik sebagai sumber tenaga penggeraknya. Sedangkan apabila mesin diesel digunakan untuk memenuhi kebutuhan listriknya, maka akan timbul masalah keuangan yang dihadapi masyarakat dalam mengoperasikannya karena kondisi perekonomian masyarakat yang masih rendah (Arianta, 2010).

Semakin besar sudut terjunan maka gaya hisap dan gaya dorong pompa hydram semakin kecil. Dari hasil penelitian pompa hydram pada tinggi terjunan $2 \mathrm{~m}$ didapatkan nilai gaya hisap yang paling besar yaitu $194,1 \mathrm{~N}$ pada sudut terjunan $35^{\circ}$ dan yang terkecil yaitu $164,6 \mathrm{~N}$ pada sudut $55^{\circ}$. Sementara gaya dorong terbesar yaitu $19,9 \mathrm{~N}$ pada sudut terjunan $35^{\circ}$ dan gaya dorong terkecil sebesar $17,2 \mathrm{~N}$ pada sudut $55^{\circ}$ (Sutanto dkk. 2019).

Sutanto dan Wirawan (2011) melakukan penelitian pompa hydram dengan ukuran 1,5 inci dengan susunan input-limbah-kompresor pada pompa hydram memiliki efisiensi terbaik pada tinggi terjunan 2,5 m dengan debit input 2,458 liter/dtk sedangkan debit output yang mampu diangkat oleh pompa sebesar 0,087 liter/dtk sedangkan tinggi angkat atau tinggi vertikal dari pompa sebesar $30 \mathrm{~m}$ serta efisiensi pompa hydram yakni sebesar 13,6\%. Sedangkan untuk susunan input-kompresorlimbah pada pompa hydram memiliki efisiensi terbaik pada tinggi terjunan $2 \mathrm{~m}$ dengan debit input 2,302 liter/dtk sedang debit output yang mampu diangkat oleh pompa sebesar 0,068 liter/dtk sedangkan tinggi angkat atau tinggi vertikal dari pompa sebesar $25 \mathrm{~m}$ serta efisiensi pompa hydram yakni sebesar $14,2 \%$.

Melihat dari kajian yang sudah ada, banyak faktor-faktor yang mempengaruhi efisiensi pompa hydram, akan tetapi penelitian - penelitian tersebut belum membahas mengenai efisiensi pompa hydram dengan penambahan pembagi tekan. Dalam penelitian ini, penulis akan mengembangkan lebih lanjut pompa hydram dengan penambahan pembagi tekan dengan memvariasikan panjang tabung pembagi tekan dan variasi tinggi pemasangan pembagi tekan.

Kemampuan pompa hydram dapat direpresentasikan dalam bentuk efisiensi D'aubuisson.

$\eta=\frac{Q_{2} H_{2}}{Q_{1} H_{1}} 100 \%$

dengan $\eta$ adalah efisiensi pompa hydram (\%), $Q_{1}$ adalah debit air terjunan atau input (liter/dtk), $Q_{2}$ adalah debit output (liter/dtk), $\mathrm{H}_{1}$ adalah tinggi terjunan air atau input $(\mathrm{m}), \mathrm{H}_{2}$ adalah tinggi air angkat atau output $(\mathrm{m})$.

Alat pembagi tekan pada prinsipnya bisa menaikan debit, hal ini disebabkan oleh kerja pompa hydram itu bersifat terputus putus (flutuasi diskontinu) saat katup buang pompa kehilangan tenaga dorong yakni saat katup tertutup, maka sesaat pompa menekan (bekerja). Saat pompa tidak menekan, maka tekanan balik dari air yang ada di dalam pipa sisi discharge akan menekan balik ke pompa, inilah yang menjadi kerugian terbesar. Ketika dipasang alat pembagi tekan, maka yang akan menekan balik ke katup masuk pompa saat pompa sedang tidak bekerja (kehilangan tenaga), hanya sepanjang pipa dari alat pembagi tekan sampai ke katup discharge pompa saja, sedangkan berat air yang ada di dalam pipa sepanjang dari alat pembagi tekan sampai ke discharge bak penampungan sudah diambil alih oleh katup satu arah yang ada didalam alat pembagi tekan sehingga tidak membebani pompa pada saat tidak memiliki tekanan.

Variasi volume tabung udara 330, 600, 1000, 1500 dan 2000 mliter pada pompa hydram, setiap variasi dilakukan pengujian sebanyak tiga kali agar supaya didapatkan data yang akurat. Terjadi kenaikkan efisiensi pompa hydram mulai pada volume 600 mliter, kemudian pada volume 2000 mliter mengalami penurunan. Pada volume 1000 mliter, penurunan efisiensi maksimum sebesar 2,46\%. Nilai ini lebih kecil dibandingkan perubahan efisiensi dari volume 600 mliter ke 1000 mliter dan dari volume 1500 mliter ke 2000 mliter. Hasil ini menunjukan bahwa tidak terjadi perubahan efisiensi yang signifikan pada variasi volume tabung. Berdasarkan analisa data, bahwa efisiensi terbesar didapat pada volume tabung udara 1500 mliter yaitu 17,21 \%. Sedangkan debit keluaran $(q)$ yang diperoleh, 
volume keluaran yang dihasilkan dalam satu hari mencapai 281,66 liter. Volume air ini setara dengan kebutuhan air 2 orang dengan asumsi setiap orang memerlukan air 140,5 liter per hari (Dinar, 2013).

Silla dkk. (2014) pengaruh diameter tabung udara dan jarak lubang pipa tekan dengan katup penghantar terhadap efisiensi pompa hydram. Tabung udara yang digunakan yaitu tabung dengan tinggi 1,2 m dengan variasi diameter 2, 2,5, 3 dan 4 inci dan jarak antara katup pengantar dengan lubang pipa pengantar yaitu $0,15,0,175,0,20,0,225$ dan $0,25 \mathrm{~m}$. Hasil penelitian menunjukkan bahwa pada penggunaan tabung udara dan jarak lubang pipa tekan memiliki masing-masing nilai efisiensi tertinggi dan terendah pada setiap kondisi, namun secara keseluruhan efisiensi tertiggi terjadi pada diameter tabung udara 2 inci dengan jarak lubang pipa tekan $22,5 \mathrm{~cm}$ sebesar $35,30 \%$ sedangkan efisiensi terendah $19,57 \%$ pada penggunaan tabung udara 2,5 inci pada jarak lubang pipa $25 \mathrm{~cm}$.

Penelitian pompa hydram dilakukan untuk mengetahui pengaruh tinggi terjunan, volume tabung udara dan tinggi discharge terhadap unjuk kerja pompa hydram. Pompa hydram yang digunakan adalah pompa hydram yang memiliki diameter pipa masuk 1 inci dan diameter pipa keluaran 0,5 inci. Variasi tinggi terjunan yaitu 1,5, 1,75, dan $2 \mathrm{~m}$. Sedangkan volume udara divariasikan sebanyak 3 variasi yang meliputi $0,00024,0,0028$ dan $0,0032 \mathrm{~m}^{3}$ dan variasi ketinggian discharge adalah 2,5, 3 dan $3,5 \mathrm{~m}$. Hasil penelitian menunjukkan bahwa unjuk kerja optimal pada pompa hydram didapat pada ketinggian terjunan $2 \mathrm{~m}$ dengan variasi volume tabung udara $0,0028 \mathrm{~m}^{3}$ dan tinggi discharge 2,5 $\mathrm{m}$, dengan kapasitas discharge sebesar 10,2 liter/menit, efisiensi volumetric $49 \%$, dan efisiensi pompa $57 \%$. Dari hasil analisa pada penelitian ini menunjukkan bahwa semakin tinggi terjunan maka energi yang masuk ke dalam pompa hydram semakin tinggi pula, keseimbangan antara tekanan yang masuk dengan tekanan dalam tabung menyebabkan katup hantar terbuka semakin cepat sehingga kapasitas discharge juga meningkat (Sofwan, 2015 ).

Nurchayati dkk. (2017) penelitian pada pompa hydram yang menunjukkan bahwa setiap kenaikan $1 \mathrm{~m}$ tinggi terjunan maka debit ouput akan mengalami kenaikan rata-rata sebesar $36,6 \%$ dan head maksimum akan meningkat sebesar 5-6 m. Variasi rasio d/h tabung kompresor berpengaruh terhadap debit output namun tidak mempengaruhi head maksimum pompa hydram. Sedangkan efisiensi tertinggi didapat pada tinggi terjunan $2 \mathrm{~m}$ dan ratio $\mathrm{d} / \mathrm{h}$ tabung kompresor 0,198 yakni sebesar $33,98 \%$.

\section{METODE PENELITIAN}

Metode yang digunakan pada penelitian ini adalah eksperimen murni dengan skema alat penelitian seperti terlihat pada gambar 1 dan gambar 2 dimana tinggi terjunan air $\left(\mathrm{H}_{1}\right)$ adalah $2 \mathrm{~m}$ sedangkan tinggi air angkat $\left(\mathrm{H}_{2}\right)$ adalah $4 \mathrm{~m}$. Semua variabel yang ditentukan dan dicari diukur langsung kecuali variabel yang harus dihitung berdasarkan variabel yang diukur. Dalam penelitian ini, ada 2 (dua) macam rangkaian alat, yaitu rangkaian pompa hydram dengan menggunakan pembagi tekan dan rangkaian pompa hydram tanpa menggunakan pembagi tekan. Hal ini dilakukan untuk mengetahui pengaruh adanya pembagi tekan terhadap efisiensi pompa hydram. Untuk mengetahui pengaruh pembagi tekan terhadap efisiensi pada pompa hydram, pada rangkaian pompa hydram menggunakan alat pembagi tekan dengan 4 variasi panjang tabung udara pembagi tekan yakni 20 $\mathrm{cm}, 30 \mathrm{~cm}, 40 \mathrm{~cm}$ dan $50 \mathrm{~cm}$ dengan diameter yang sama yaitu 1,5 inch serta 3 variasi tinggi pemasangan alat pembagi tekan yakni $2 \mathrm{~m}, 2,5 \mathrm{~m}$ dan $3 \mathrm{~m}$ dari badan pompa sedangkan tinggi terjunan air $\left(\mathrm{H}_{1}\right)$ adalah $2 \mathrm{~m}$ dan tinggi air angkat $\left(\mathrm{H}_{2}\right)$ adalah $4 \mathrm{~m}$.

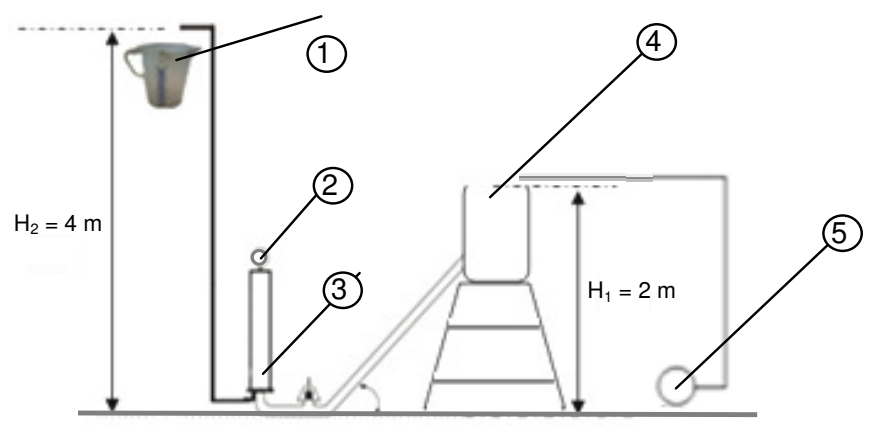

Gambar 1. Skema alat penelitian pompa hydram tanpa pembagi tekan. 1. gelas ukur (output), 2. presure gauge, 3. pompa hydram, 4. reservoar (input), 5. pompa air pengisi sumber. 
Dalam pengambilan data pada penelitian ini dilakukan dengan tiga kali pengulangan untuk setiap variasi yang digunakan, dari tiga kali pengulangan tersebut diambil nilai rata - rata untuk hasil yang akan digunakan dalam perhitungan. Dengan penelitian yang sudah dilakukan maka diperoleh data-data variabel seperti debit limbah, debit air yang dipompakan, tekanan keluaran, tekanan maksimum dan efisiensi.

Tabel 1. Alat dan bahan

\begin{tabular}{ll}
\hline Nama & Spesifikasi \\
\hline Pompa hydram & Badan pompa 1,5", tabung kompresor 3" \\
Alat pembagi tekan & Diameter 1,5" \\
Presure gauge & Max 2,5 kg/cm² \\
Reservoir & 1500 liter \\
Gelas ukur & 1,5 liter \\
\hline
\end{tabular}

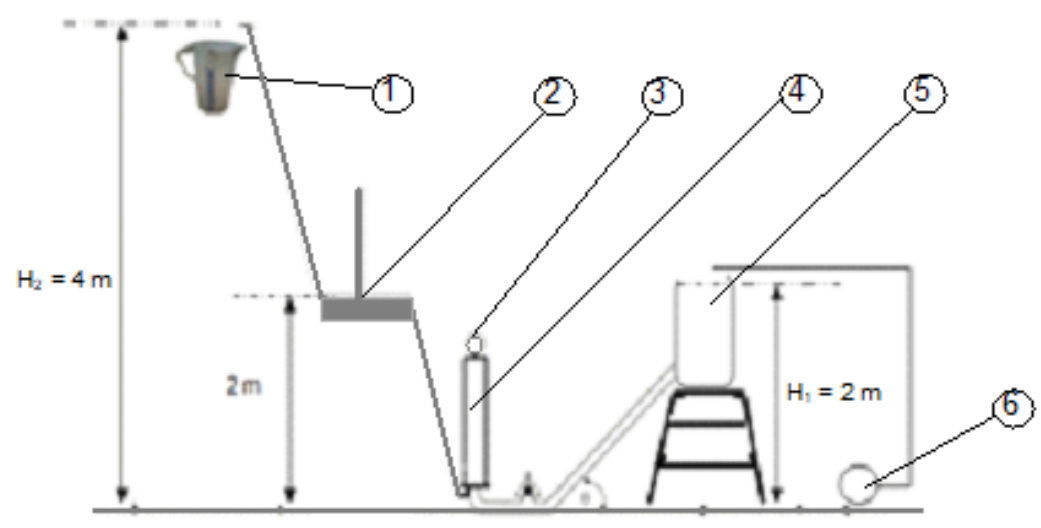

Gambar 2. Skema alat penelitian pompa hydram menggunakan alat pembagi tekan. 1. gelas ukur (output), 2. alat pembagi tekan, 3. presure gauge, 4. pompa hydram, 5. reservoar (Input), 6. pompa air pengisi sumber.
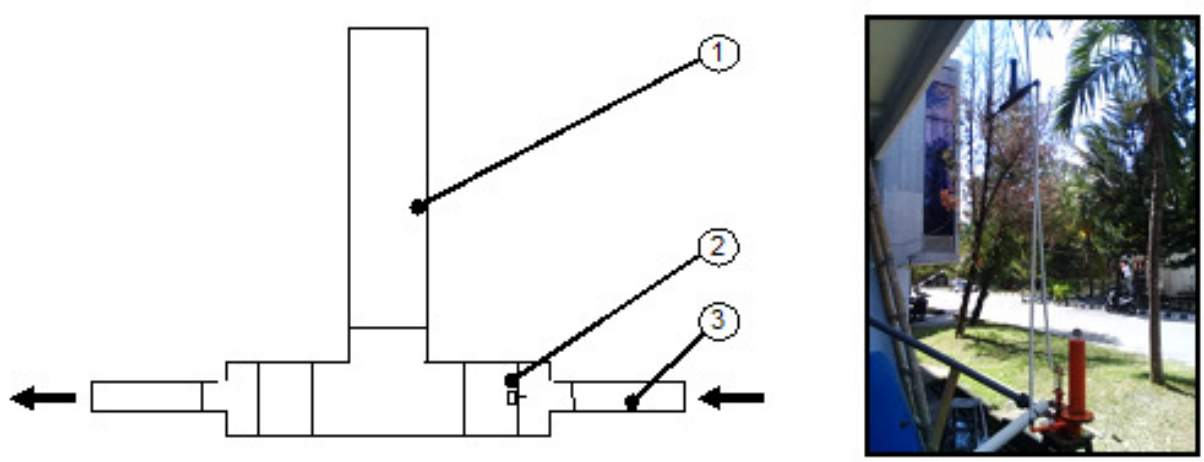

Gambar 3. Alat pembagi tekan. 1. tabung udara, 2. katup satu arah, 3. saluran air masuk

\section{HASIL DAN PEMBAHASAN}

Pada gambar 4 terlihat bahwa panjang tabung pada alat pembagi tekan berbanding terbalik dengan head maksimum yang dicapai. Head maksimum tertinggi diperoleh pada penggunaan panjang tabung $20 \mathrm{~cm}$ pada tinggi pemasangan $2 \mathrm{~m}$ dari badan pompa yaitu $5,66 \mathrm{~m}$ dan head maksimum terendah diperoleh pada penggunaan panjang tabung $50 \mathrm{~cm}$ pada tinggi pembagi tekan $3 \mathrm{~m}$ dari badan pompa yaitu $5,40 \mathrm{~m}$. Hal itu terjadi karena pada perlakuan yang sama dimana debit air yang memasuki alat pembagi tekan sama, gaya tekan air sama dan diameter tabung pembagi tekan sama, maka volume udara yang terjebak pada tabung udara pembagi tekan berbeda karena tinggi tabung udara berbeda akibatnya tabung udara $20 \mathrm{~cm}$ pada penelitian ini memiliki rasio kompresi lebih tinggi 
dari pada tabung udara $30 \mathrm{~cm}, 40 \mathrm{~cm}$ maupun yang $50 \mathrm{~cm}$. Hasil analisa data didapatkan bahwa semakin panjang tabung udara, maka rasio kompresi akan menurun yang artinya tekanan menurun, akibatnya head maksimum akan menurun.

Tabel 2. Head maksimum pompa hydram

\begin{tabular}{ccccc}
\hline & \multicolumn{4}{c}{$\mathrm{H}$ max $(\mathrm{m})$} \\
\hline \multirow{2}{*}{$\begin{array}{c}\text { Tanpa pembagi } \\
\text { tekan }(\mathrm{m})\end{array}$} & $\begin{array}{c}\text { Pengan pembagi tekan } \\
\text { tabung }(\mathrm{cm})\end{array}$ & $2 \mathrm{~m}$ & $2,5 \mathrm{~m}$ & $3 \mathrm{~m}$ \\
\cline { 2 - 5 } & 20 & 5,66 & 5,63 & 5,56 \\
5,51 & 30 & 5,57 & 5,54 & 5,49 \\
& 40 & 5,53 & 5,50 & 5,43 \\
& 50 & 5,48 & 5,45 & 5,40 \\
\hline
\end{tabular}

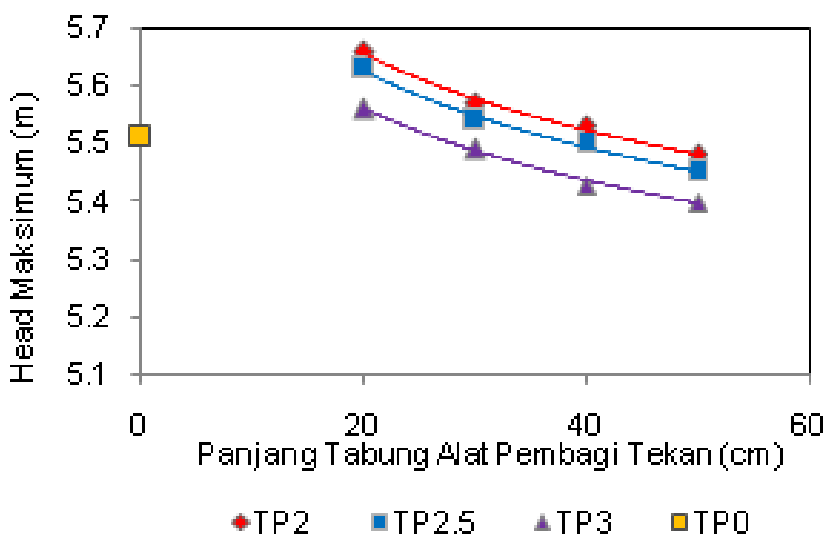

Gambar 4. Hubungan antara panjang tabung alat pembagi tekan dengan head maksimum.

Tabel 3. Efisiensi pompa hydram

\begin{tabular}{|c|c|c|c|c|}
\hline \multicolumn{5}{|c|}{ Efisiensi (\%) } \\
\hline \multirow{3}{*}{$\begin{array}{l}\text { Tanpa pembagi } \\
\text { tekan }(\mathrm{m})\end{array}$} & \multicolumn{4}{|c|}{ Dengan pembagi tekan } \\
\hline & \multirow{2}{*}{$\begin{array}{l}\text { Panjang } \\
\text { tabung }(\mathrm{m})\end{array}$} & \multicolumn{3}{|c|}{ Tinggi pemasangan } \\
\hline & & $2 \mathrm{~m}$ & $2,5 \mathrm{~m}$ & $3 \mathrm{~m}$ \\
\hline \multirow{4}{*}{26,62} & 20 & 31,62 & 29,76 & 28,88 \\
\hline & 30 & 31,12 & 29,46 & 28,40 \\
\hline & 40 & 30,11 & 28,65 & 27,17 \\
\hline & 50 & 29,29 & 28,08 & 26,99 \\
\hline
\end{tabular}

Gambar 5 terlihat bahwa efisiensi pompa hydram berbanding terbalik dengan tinggi pemasangan pembagi tekan dan panjang tabung pembagi tekan. Efisiensi tertinggi terjadi pada penggunaan panjang tabung $20 \mathrm{~cm}$ pada pemasangan pembagi tekan dengan tinggi $2 \mathrm{~m}$ dari badan pompa yaitu $31,62 \%$, dan efisiensi terendah terjadi pada penggunaan panjang tabung $50 \mathrm{~cm}$ pada pemasangan alat pembagi tekan dengan tinggi $3 \mathrm{~m}$ dari badan pompa yaitu $26,99 \%$. Hal ini terjadi karena penambahan panjang tabung pada pembagi tekan justru akan menurunkan tekanan pada alat pembagi tekan pada pompa hydram (gambar 4), akibatnya debit yang dihasilkan akan menurun. Berdasarkan tinggi pemasangan pembagi tekan, Efisiensi tertinggi pada tinggi pemasangan pembagi tekan $2 \mathrm{~m}$ dari badan pompa dan efisiensi terendah pada tinggi pemasangan $3 \mathrm{~m}$ dari badan pompa. Hal ini cukup beralasan, karena tinggi keluaran berbanding terbalik dengan debit air yang dipompakan, semakin tinggi keluaran maka debit air yang dipompakan akan menurun demikian pula sebaliknya jika debit semakin besar maka tinggi keluaran semakin rendah. Hal ini akan memberikan pengaruh yakni efisiensi pompa hydram akan berkurang. Karena debit yang dipompakan berbanding 
lurus dengan efisiensi pompa hydram. Semakin besar debit yang dipompakan maka efisiensi pompa hydram akan meningkat, begitupun sebaliknya.

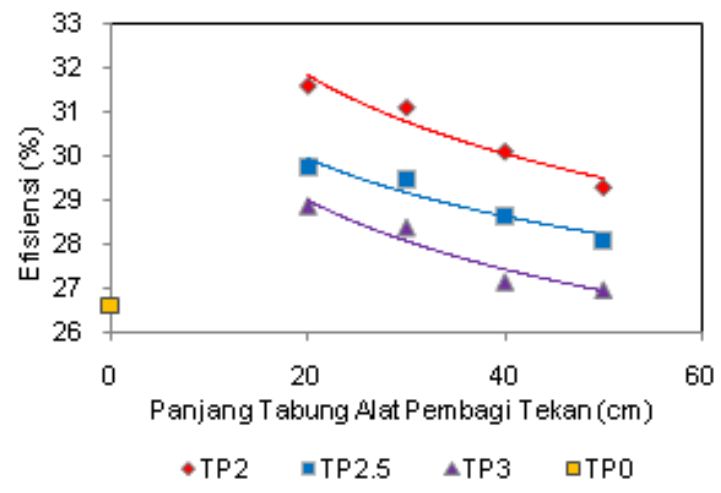

Gambar 5. Hubungan antara panjang tabung alat pembagi tekan dengan efisiensi.

Berdasarkan gambar 5 terlihat bahwa efisiensi pompa hydram tanpa pemasangan alat pembagi tekan lebih rendah dari pada pompa hydram dengan pemasangan alat pembagi tekan. Hal ini terjadi karena pada pompa hydram tanpa pemasangan alat pembagi tekan, air yang dipompakan mengalir tidak kontinu. Berbeda halnya dengan pemasangan alat pembagi tekan pada pompa hydram. Berdasarkan pengamatan pompa hydram dengan pemasangan alat pembagi tekan, getaran akibat palu air hilang dan air yang dipompakan mengalir secara kontinu karena adanya tabung pada alat pembagi tekan yang dapat menstabilkan debit air sehingga pada waktu yang sama debit air yang dipompakan lebih besar dari pada pompa hydram tanpa pemasangan alat pembagi tekan, akibatnya efisiensi akan semakin meningkat. Efisiensi tertinggi terjadi pada penggunaan panjang tabung $20 \mathrm{~cm}$ pada pemasangan alat pembagi tekan dengan tinggi $2 \mathrm{~m}$ dari badan pompa yaitu $31,62 \%$ untuk tinggi terjunan $2 \mathrm{~m}$. Pada penelitian sebelumnya yang telah dilakukan oleh Sutanto dan Wirawan (2011) untuk pompa hydram tanpa penambahan alat pembagi tekan menunjukan bahwa pada tinggi terjunan $2,5 \mathrm{~m}$ memiliki efisiensi pompa hydram yakni sebesar $13,6 \%$ dan pada tinggi terjunan $2 \mathrm{~m}$ mempunyai efisiensi pompa hydram yakni sebesar $14,2 \%$. Sehingga jika dibandingkan dengan penelitian Sutanto dan Wirawan (2011) menunjukan bahwa pompa hydram dengan penambahan alat pembagi tekan memiliki efisiensi yang jauh lebih baik.

\section{KESIMPULAN}

Dari hasil penelitian dan pembahasan tersebut dapat disimpulkan beberapa hal. Penggunaan alat pembagi tekan berpengaruh terhadap efek palu air. Tanpa pemasangan alat pembagi tekan, pompa hydram bergetar cukup besar, namun dengan adanya alat pembagi tekan getaran akibat palu air pada pompa hydram berkurang dan pada pipa keluaran alat pembagi tekan getaran hilang. Penggunaan alat pembagi tekan berpengaruh terhadap efisiensi pompa hydram. Tanpa alat pembagi tekan efisiensi pompa hanya $26,62 \%$, namun dengan pemasangan alat pembagi tekan efisiensi pompa meningkat yaitu yang tertinggi hingga mencapai $31,62 \%$. Panjang tabung pada alat pembagi tekan memiliki pengaruh terhadap efisiensi pompa hydram. Panjang tabung alat pembagi tekan pada pompa hydram tidak berbanding lurus dengan efisiensi pompa hydram, efisiensi pompa hydram tertinggi pada penggunaan panjang tabung $20 \mathrm{~cm}$ yaitu $31,62 \%$ dan efisiensi terendah pada panjang tabung $50 \mathrm{~cm}$ yaitu $26,99 \%$. Semua berlaku pada berbagai posisi pemasangan alat pembagi tekan. Tinggi pemasangan alat pembagi tekan berpengaruh terhadap efisiensi pompa hydram. Efisiensi pompa hydram tertinggi pada pemasangan alat pembagi tekan pada tinggi $2 \mathrm{~m}$ dari badan pompa yaitu $31,62 \%$ dan efisiensi pompa hydram terendah pada pemasangan pembagi tekan $3 \mathrm{~m}$ dari badan pompa yaitu $26,99 \%$.

\section{DAFTAR NOTASI}

TP2 :Tinggi pemasangan alat pembagi tekan yakni $2 \mathrm{~m}$ dari badan pompa

TP2,5 : Tinggi pemasangan alat pembagi tekan yakni $2,5 \mathrm{~m}$ dari badan pompa

TP3 : Tinggi pemasangan alat pembagi tekan yakni $3 \mathrm{~m}$ dari badan pompa

TPO : Tanpa alat pembagi tekan 


\section{DAFTAR PUSTAKA}

Arianta A.N., 2010, Pengaruh variasi ukuran tabung udara terhadap unjuk kerja sebuah pompa hydram, Program Studi Teknik Mesin Jurusan Teknik Mesin Fakultas Teknik Universitas Gadjah Mada, Yogyakarta.

Dinar M.F., 2013, Uji efisiensi pompa hidram dengan variasi volume tabung udara, Prosiding Seminar Kontribusi Fisika (SKF2013), Bandung.

Muliadi, Bonita M.K., Ruwaidah E., 2015, Aplikasi pompa hydram untuk penyediaan air bersih di desa Menemeng Lombok Tengah, Universitas Nusa Tenggara Barat, Mataram.

Nurchayati, Mulyanto A., Sutanto R., Wardani K., 2017, Pengaruh variasi tinggi terjunan dan dimensi tabung kompresor terhadap unjuk kerja pompa hydram, Jurnal Mesin ITB, 26(2), 91-101.

Silla C., Jafri M., Limbong I.S., 2014, Pengaruh diameter tabung udara dan jarak lubang pipa tekan dengan katup penghantar terhadap efisiensi pompa hidram, Jurnal LONTAR Undana, 1(2), 1-7.

Sofwan M., 2015, Pengaruh ketinggian terjunan dan volume tabung udara terhadap kinerja pompa hidram, Universitas Negeri Surabaya, Surabaya, 2015.

Sutanto R., Wirawan M., 2011, Analisa pengaruh variasi susunan terhadap kemampuan unjuk kerja pompa hydram ditinjau dari aspek tinggi terjunan, Jurnal Dinamika Teknik Mesin, 1(1), 21-25.

Sutanto R., Wardani K., Wirawan M., Salman, 2019, Variasi sudut pipa masukan terhadap unjuk kerja pompa hydram, Jurnal Dinamika Teknik Mesin, 9(1), 7-14. 